\title{
The Irish pharmaceutical industry over the boom period and beyond
}

\author{
Chris van Egeraat ${ }^{a *}$ and Frank Barry ${ }^{\mathrm{b}}$ \\ ${ }^{a}$ National Institute for Regional and Spatial Analysis and Department of Geography, National \\ University of Ireland, Maynooth, Ireland; ${ }^{b}$ School of Business, Trinity College Dublin, Ireland
}

\begin{abstract}
The pharmaceutical industry was one of the strongest performing sectors of the Celtic Tiger era. During the past two decades, employment growth in the sector has been strong and continuous, even when, in recent years, employment in other manufacturing sectors has been contracting. Although positive in itself, from a dynamic regional development perspective it is important to explore the qualitative changes in the types of activities that are conducted in Ireland. Adopting a global production network approach, the paper examines Ireland's changing role in global production networks within the pharmaceutical industry, focusing on the different components of manufacturing and research and development (R\&D). The analysis shows that Ireland's involvement in manufacturing has shifted in the direction of relatively higher value generating activities. Within R\&D, although the level of value creation has increased substantially, Ireland's involvement nonetheless remains concentrated in the (relatively) lower value generating activities of the global R\&D network. In addition, the sector remains strongly dominated by foreign companies so that a large share of the created value is not captured within Ireland
\end{abstract}

Keywords: R\&D; pharmaceutical; Ireland; global production networks

\section{Introduction}

The pharmaceutical sector is of substantial importance to Ireland. It accounts for almost $16 \%$ of industrial exports and some $5 \%$ of manufacturing employment, and is one of the highest-skill sectors of manufacturing industry. Yet, the developmental aspects of the sector have been little researched. This paper provides a detailed account of the dynamics of the Irish pharmaceutical industry over recent decades. The paper engages principally with the regional development literature and employs the Global Production Network (GPN) framework that seeks to shed light on the relation between economic integration, globalisation and regional development (Dicken et al. 2001, Yeung et al. 2001, Henderson et al. 2002). This framework proposes that the globalisation of production networks of firms and institutions integrates economies in ways which have important implications for development. We analyse Ireland's changing role in the global production networks of the pharmaceutical industry, notably with respect to R\&D and manufacturing.

The analysis is based on statistical data from national and international institutions, on semi-structured face-to-face interviews with senior staff at 12 selected pharmaceutical companies conducted in 2005-2006 and on an email survey of all existing pharmaceutical establishments conducted in 2006.

*Corresponding author. Email: chris.vanegeraat@nuim.ie 
The semi-structured interviews provided information on the changing role of Irish subsidiaries in the global production networks of pharmaceutical companies. The 12 companies selected for detailed study were chosen so as to represent different countries of origin, different activities (bio-pharmaceutical vs. chemical pharmaceutical) and different geographical locations in Ireland. The sample included US (5), British (2), Irish (2), Japanese (1), Swiss (1) and French (1) companies. A total of 52 senior staff members were interviewed, including general managers, materials managers, personal managers and managers of R\&D. The aim of the email survey was to quantify the scale and scope of production process R\&D activities in the Irish industry. Process development managers or managers of technical services in all (80) pharmaceutical firms were approached and asked to complete a two-page questionnaire. Seventy six useable questionnaires were returned - a response rate of $95 \%$. Further detail regarding the survey methodology and response is provided below (see also van Egeraat 2007).

The paper begins with a discussion of the role of global production networks as discussed in the regional development literature. This is followed by an account of the development of the Irish pharmaceutical industry. Following a description of the value chain of the industry, the paper presents a detailed investigation of the qualitative changes in Ireland's role in manufacturing (of both active ingredients and drug formulations) and various elements of the R\&D cycle (including discovery, clinical trials and process development) and then offers some concluding comments.

\section{Global production networks}

Geographers have been active participants in the analysis of regional economic development. Following the seminal work of Piore and Sabel (1984), many studies emphasised the role of internal production linkages, local institutions and indigenous firms. Another body of work has concentrated on external linkages, notably the impact of subsidiaries of multinational enterprises on local and national development. Some of the work undertaken in the 1990s assessed the salience of upgrading processes towards quality/performance plants (Amin et al. 1994), developmental subsidiaries (Young et al. 1994), and the latter's developmental linkages (Turok 1993). Recent work has taken a more dynamic perspective by analysing the developmental impact of industrial change and the related organisational dynamics of multinational enterprises (MNEs) (Phelps 1993, Hudson 1994, Hudson 1997, Pike 1998, Yeung 2000). All of these papers draw on the management and international business literature on corporate strategy/structure (e.g. Bartlett and Ghoshal 1989) and subsidiary roles (e.g. White and Poynter 1984, Hedlund and Rolander 1990, Young et al. 1988).

In searching for an overall framework for understanding issues of global integration and local economic development, Gerreffi and others developed the Global Commodity Chain (GCC) framework (Gereffi and Korzeniewicz 1994, Bair and Gereffi 2001, Gerreffi 2001), which privileges the dynamics of global industries and the role of external linkages in understanding regional economic development. Building on the GCC concept, Dicken et al. (2001) propose a Global Production Network (GPN) framework (see also Yeung et al. 2001, Henderson et al. 2002), which emphasises the role of the firm and networks of firms. The idea is that production networks of firms and institutions have become increasingly global and 
integrate economies in ways which have important implications for development. An understanding of the economic development implications for regions requires a study of the dynamics of "what [lead-] firms do, where they do it, why they do it, why they are allowed to do it and how they organise the doing of it across different geographic scales' (Henderson et al. 2002, p. 5).

Like the GCC framework, the GPN framework acknowledges the importance of external linkages in seeking to understand the dynamics of local and regional development. However, the GPN perspective explicitly accords a degree of power and autonomy to domestic firms, governments and institutions whose actions can influence the economic outcomes of the network processes in their own locations. Furthermore, the GPN framework more explicitly acknowledges that input-output flows can be organised horizontally and diagonally as well as vertically. A particularly appealing aspect of the approach is that it recognises the multi-scalar nature of GPNs and the forces underlying regional development. Such a view breaks with the idea of a global-local dichotomy and allows for the nesting of local clusters with arguments about globalisation (Sturgeon 2000). In relation to regional development policy it suggests the need for a favourable 'strategic coupling' between the needs of the various global production networks and the resources and needs of the region (Coe et al. 2004)

The GPN perspective directs attention to the networks of firms involved in the whole range of activities linked to a given product (including $\mathrm{R} \& \mathrm{D}$, design, production, marketing and other services), the way these are organised globally, the way this global organisation is influenced by governments and institutions, and the overall implications for upgrading and development. It provides an elaborate conceptual framework for linking corporate processes to regional development. One of the central concepts in the analysis of inter-organisational connections and how they relate to the economic development of particular localities is value; specifically the way in which it is created and the extent to which it is captured in various locations. Part of the contribution of the present paper is to analyse Ireland's changing role in global production networks and what this means in terms of value creation. Before this, we present an account of Ireland's emergence as an important player in the global pharmaceutical industry.

\section{The growth of the Irish pharmaceutical industry}

The development of the Irish pharmaceutical industry has been, and continues to be, a major international success story. Until the 1960s there was virtually no pharmaceutical industry in Ireland (Galvin 1998). The post-independence autarkic economic development policies, including the Control of Manufacturers Act (designed to keep the ownership of industry in native hands), offered little incentive for foreign companies to invest in Ireland (White 2000b), while the manufacturing of most pharmaceutical products was too sophisticated and capital-intensive for indigenous players. The first substantial investments by foreign pharmaceutical companies followed rapidly on from the shift towards more outward-looking economic policies towards the end of the 1950s (van Egeraat 2006, van Egeraat and Breathnach 2007). However, the sector really took off in the 1970s following the Industrial Development Authority's (IDA) adoption of fine chemicals as one of its 
target sectors (Childs 1996). This led to a series of manufacturing investments, notably by US- and UK-based companies.

Figures 1 and 2 chart the growth of employment in the pharmaceuticals sector in Ireland in the periods 1979-1991 and 1991-2005 respectively, using CSO data. There is a structural break in the data as the industrial classification system changed in 1991. At the beginning of the period, the sector accounted for around 2500 jobs and just $1 \%$ of manufacturing employment. By 2005, employment numbers in the now more narrowly defined sector had grown to 11,000 and the sector accounted for $5 \%$ of Irish manufacturing employment. While overall manufacturing employment has fluctuated over the last decade, recording largely similar numbers for 1995 and 2005, the pharma sector is one of the few to have recorded almost continuous employment growth over the period (apart from what might be viewed as a positive upward blip in 2002).

The Forfás employment survey records far higher employment numbers for the sector than the CSO figures. Using this data set, van Egeraat (2006) shows that in 2003 the industry already employed 19,500 workers (see also Figure 3). Again, the data paint a picture of strong and nearly continuous employment growth since the early 1970 s - even after 2001, when employment in most other manufacturing sectors contracted.

The continuing growth of employment in the Irish pharmaceutical industry, even at a time when employment in other manufacturing industries started to decline has significantly increased the relative importance of the pharmaceutical industry. Table 1 shows how the share of the pharmaceutical industry in total manufacturing employment has increased from under $2 \%$ in 1990 to $5.2 \%$ in 2005 , by far the highest figure for any OECD economy.

The quality of the jobs further increases the importance of the industry. Pharmaceuticals are by all available measures one of the highest-skill sectors within Irish manufacturing. Skill intensity is typically proxied either by the share of thirdlevel graduates in sectoral employment or, more directly, by wage levels per employee. Table 2 shows that the broad chemicals sector (of which pharma is a significant component), records the highest skill levels, using the share of third-level graduates as indicator, while Table 3 shows that this sector, with the lower-tech

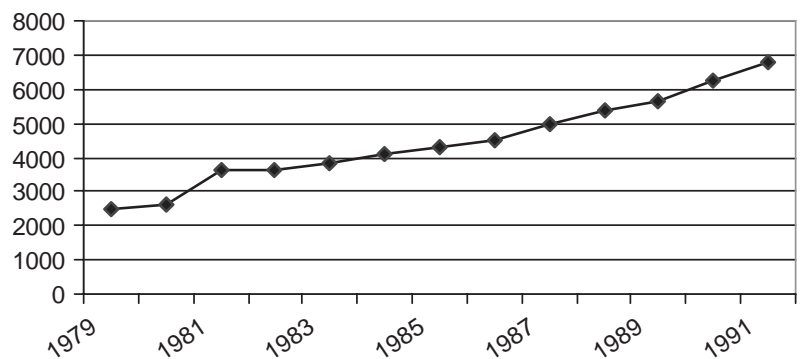

Figure 1. Employment in pharmaceuticals (NACE 257) in Ireland, 1979-1991.

Source: Census of Industrial Production (various issues)

Note: CIP (1991) yields employment numbers for both NACE 257 and NACE 244 for that year 


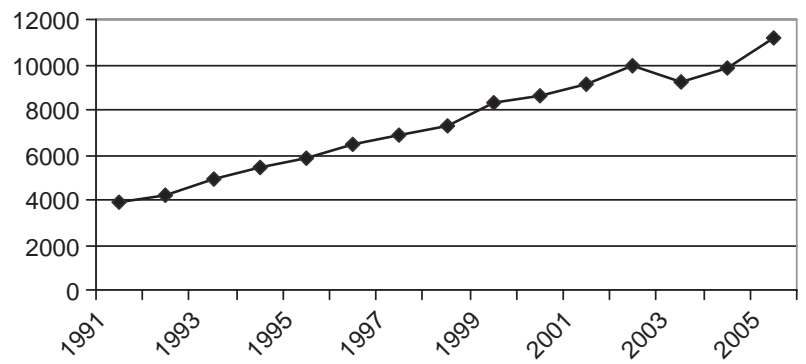

Figure 2. Employment in pharmaceuticals (NACE 244) in Ireland, 1991-2005.

Source: Census of Industrial Production (various issues)

rubber and plastics segment stripped out, records the highest wage levels, although wages in pharma are marginally below those in the rest of the sector.

Ireland has become an important exporter of pharmaceutical products. Table 4 displays the shares of global pharmaceutical exports recorded for various countries over the period 1965-2005. The shares emanating from traditional pharma exporting countries such as the US, the UK, Switzerland and Germany have all substantially shrunk. In contrast, Ireland's market share in pharmaceuticals has grown substantially, particularly during the Celtic Tiger era and beyond. The expansion of Ireland's market share is all the more remarkable in that it has not been replicated by other non-traditional exporting countries, with the exception of Belgium.

India and China, for example, are yet to become major global exporters of pharmaceuticals. India's share of global pharma exports has hovered around 1\% since 1980; while exports by the Chinese pharmaceutical industry are even less important, accounting for only $0.5 \%$ of global exports in 2005 . Malaysian and South Korean pharma exports are also insignificant, while, perhaps surprisingly, Israel and Singapore hover at around only $1 \%$ each.

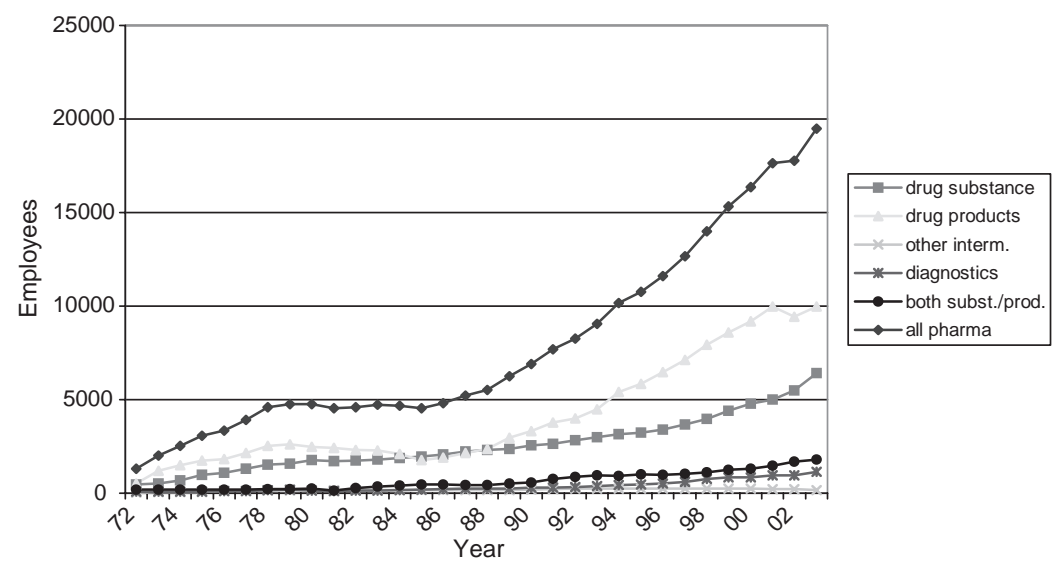

Figure 3. Pharmaceutical industry employment by sub-sector 1972-2003.

Source: van Egeraat 2006, based on Forfás Employment Survey 
Table 1. Share of pharmaceutical sector in manufacturing employment, 1985-2000, various countries.

\begin{tabular}{lccccc}
\hline & $\mathbf{1 9 8 5}$ & $\mathbf{1 9 9 0}$ & $\mathbf{1 9 9 5}$ & $\mathbf{2 0 0 0}$ & $\mathbf{2 0 0 5}$ \\
\hline European Union (15 countries) & 1.5 & 1.7 & 2 & 2 & \\
Belgium & & & 2.1 & 2.6 & 3.3 \\
Denmark & 2.3 & 3.1 & 3.7 & 2.7 & \\
Germany & 1.2 & 1.3 & 1.6 & 1.7 & 1.7 \\
Ireland & $\mathbf{1 . 3}$ & $\mathbf{1 . 9}$ & $\mathbf{2 . 6}$ & $\mathbf{3 . 4}$ & $\mathbf{5 . 2}$ \\
Greece & 2 & 2.3 & 2.4 & 1.7 & \\
Spain & 1.6 & 1.6 & 1.8 & 1.4 & 1.5 \\
France & 2 & 2.5 & 2.7 & 3 & 2.8 \\
Italy & 2 & 2.3 & 1.4 & 1.5 & 1.5 \\
Netherlands & 1.7 & 1.6 & & 2 & \\
Austria & & & 1.4 & 2 & 1.6 \\
Portugal & & 0.9 & 0.9 & 0.8 & \\
Finland & & 0.9 & 1.5 & 1.4 & 1.0 \\
Sweden & 1.5 & 2.2 & 2.8 & \\
United Kingdom & 1.3 & 1.5 & 2 & $2.1 *$ & 2.1 \\
United States & 0.9 & 1 & 1.3 & & \\
Japan & 0.9 & 0.9 & 1 & & \\
\hline
\end{tabular}

Source: Eurostat Annual Enterprise Statistics

Note: the 1985-2000 figures refer only to enterprises employing 20 or more persons

* refers to 2001; blank cells indicate data not available.

In 2006, Irish pharmaceutical exports were worth around $\$ 17$ billion. This accounted for almost $16 \%$ of Irish industrial exports and over $6 \%$ of world pharmaceutical exports; while Irish industrial exports overall comprised less than 1\% of world industrial exports. The Irish industry's growth has been largely based on foreign direct investment however. In 2003, subsidiaries of foreign companies accounted for $93 \%$ of pharmaceutical employment and virtually all employment in the drug substance sub-sector. Indigenous operations remained relatively small with only seven indigenous companies employing more than 50 staff (van Egeraat and Breathnach 2007).

While pharma imports came to only around $\$ 2$ billion $^{1}$, it must be recognised that a large share of the value of the exports is not added in Ireland. Apart from the import of raw and intermediate materials, all of Ireland's foreign-owned manufacturing sectors make substantial payments to their overseas parent companies in the form of royalties and licence fees and payments for miscellaneous business services. In addition, there is a widespread suspicion that the country's trade surplus in pharmaceuticals is inflated by the behaviour of corporations who face an incentive to shift profits to low-corporation-tax locations such as Ireland. One way in which this can be done is through the manipulation of 'transfer prices' (the prices charged for the transfer of goods and services between a parent company and its foreign affiliates). ${ }^{2}$ Some indications of the possible extent of transfer pricing in the Irish pharmaceuticals case are suggested by the data in Table 5. Gross value added per person employed in the sector in Ireland is more than double the EU15 average and one and a half times the level prevailing in the UK sector; while the share of 
Table 2. Third-level graduates as share of sectoral employment, 2006.

\begin{tabular}{lcc}
\hline & $\begin{array}{c}\text { Third-level graduates } \\
\text { as share of sectoral } \\
\text { employment }\end{array}$ & $\begin{array}{c}\text { Third-level graduates with } \\
\text { degree or higher as share of } \\
\text { sectoral eEmployment }\end{array}$ \\
\hline Manufacturing industries & $\mathbf{3 2 . 8}$ & $\mathbf{1 9 . 9}$ \\
$\begin{array}{l}\text { Food industries } \\
\text { Beverages and tobacco }\end{array}$ & 23.4 & 14.2 \\
$\begin{array}{l}\text { Textiles, clothing, footwear } \\
\text { and leather }\end{array}$ & 42.5 & 27.9 \\
$\begin{array}{l}\text { Wood and wood products } \\
\text { Paper, paper products, print- }\end{array}$ & 18.9 & 9.9 \\
$\quad$ ing and publishing & 17.3 & 9.1 \\
$\begin{array}{c}\text { Chemical, rubber and plastic } \\
\text { products }\end{array}$ & 35.9 & $\mathbf{3 1 . 2}$ \\
$\begin{array}{l}\text { Glass, pottery and cement } \\
\text { Metals, metal products, ma- } \\
\text { chinery and engineering }\end{array}$ & $\mathbf{4 5 . 7}$ & 10.0 \\
$\begin{array}{l}\text { Other manufacturing (incl. } \\
\text { transport equipment) }\end{array}$ & 18.6 & 21.8 \\
\hline
\end{tabular}

Source: Population Census 2006, Volume 10: Education and Qualifications; Table 8.

personnel costs in production is substantially lower than in either of the other geographic entities. ${ }^{3}$

Profit outflows from Ireland's FDI-intensive pharmaceutical sector are very substantial as many foreign parents take substantial dividend payments from their Irish units (Beesley 2005). Thus, although much value may appear to be created in Ireland, a large share of this value is not captured in Ireland.

We have seen that the level of economic activity in the Irish pharmaceutical industry has increased substantially over recent decades and that Ireland has become one of the main pharmaceutical exporters. The remainder of the paper will analyse in more detail Ireland's changing role in the global production networks of the pharmaceutical industry.

\section{The value chain of the pharmaceutical industry}

A basic model of the value chain of the pharmaceutical industry includes the following segments: discovery, product development or clinical trials, process R\&D, active ingredient manufacturing, drug product (formulation) manufacturing; sales and marketing; and corporate functions. Discovery covers the initial product R\&D activities, i.e. research into the causes of diseases and the identification of compounds that have a pharmacological effect. Product development includes the further development of these compounds, and notably their testing in pre-clinical and clinical trials. Process R\&D is concerned with the development of safe and efficient manufacturing processes at commercial scale. Manufacturing encompasses the production of raw materials, intermediates, active ingredients and drug products (formulations). All these activities are supported by corporate functions such as strategic and supply chain management and finance. 
Table 3. Wages per head by industrial sector.

\begin{tabular}{lc}
\hline Sector & 2004 \\
\hline Manufacturing industries & 32,126 \\
Food beverages and tobacco & 31,493 \\
Textiles & 23,382 \\
Clothing & 22,315 \\
Leather & 21,575 \\
Wood and wood products & 25,660 \\
Pulp and paper & 35,257 \\
Publishing & 35,325 \\
Chemicals & $\mathbf{3 9 , 4 9 8}$ \\
of which: Pharmaceuticals & $\mathbf{3 8 , 8 8 3}$ \\
Rubber and plastics & 27,660 \\
Non-metallic minerals & 30,099 \\
Basic and fabricated metals & 28,196 \\
Machinery and equipment nec. & 29,361 \\
Office machinery and computers & 35,714 \\
Electrical machinery & 29,805 \\
Radio, TV, and medical devices & 31,382 \\
Transport equipment & 33,472 \\
Manufacturing nec and fuels & 26,407 \\
\hline
\end{tabular}

Source: Census of Industrial Production, Manufacturing Local Units

The various segments account for different levels of value creation. It is difficult (and beyond the scope of this paper) to quantify these levels, partly because the concept is not easy to operationalise. ${ }^{4}$ One option is to apply the notion of valueadded, which is occasionally employed by the original proponents of the GPN approach (Henderson et al. 2002, p. 28). Value-added refers to the additional value of an output over the cost of the inputs used to produce it from the previous stage of

Table 4. Country shares of global pharma exports, 1965-2005, selected countries.

\begin{tabular}{lrrrrrrrrr}
\hline & 1965 & 1970 & 1975 & 1980 & 1985 & 1990 & 1995 & 2000 & 2005 \\
\hline Ireland & 0.6 & 0.7 & 1.2 & 1.2 & 1.2 & 2.7 & 3.2 & 4.5 & 6.6 \\
Japan & 2.0 & 2.1 & 1.6 & 2.1 & 2.3 & 2.5 & 1.5 & 2.0 & 1.0 \\
USA & 15.3 & 13.2 & 11.5 & 14.4 & 16.7 & 11.9 & 8.2 & 11.4 & 8.7 \\
UK & 11.3 & 10.5 & 10.8 & 12.3 & 11.1 & 11.5 & 12.1 & 11.1 & 8.6 \\
Switzerland & 10.9 & 10.3 & 11.0 & 11.4 & 9.6 & 12.4 & 10.7 & 9.1 & 9.0 \\
Italy & 3.6 & 4.8 & 5.0 & 4.9 & 5.1 & 4.3 & 4.1 & 5.9 & 4.7 \\
France & 8.2 & 7.2 & 8.3 & 10.6 & 9.2 & 10.4 & 10.4 & 10.2 & 8.8 \\
Germany & 27.6 & 30.7 & 27.8 & 16.1 & 14.2 & 16.7 & 14.8 & 12.7 & 14.6 \\
Netherlands & 8.4 & 4.4 & 4.3 & 4.4 & 3.6 & 3.9 & 5.4 & 4.1 & 4.1 \\
Belgium* & 1.8 & 2.6 & 4.1 & 4.7 & 4.0 & 4.6 & 7.2 & 7.4 & 14 \\
Spain & 0.1 & 0.4 & 0.5 & 1.4 & 1.4 & 1.8 & 1.2 & 1.8 & 2.5 \\
\hline
\end{tabular}

Source: UN Comtrade database

*Belgium and Luxembourg until 1995; Belgium alone for 2000 and 2005 (Exports from Luxembourg are insignificant). 
Table 5. Indications of possible transfer price manipulation in the Irish pharma sector, 2001.

Gross value added per person

employed (thousands of euro)
Share of personnel costs in production

\begin{tabular}{llllllll}
\hline Industry & NACE codes & EU15 & UK & Irl & EU15 & UK & Irl \\
Pharmaceuticals & 24.4 & 106.3 & 141.1 & 251 & 18.5 & 20.1 & 7.2 \\
\hline
\end{tabular}

Source: Barry 2005

production. High value added is generally related to a strong positive impact on economic development.

Discovery, clinical trials and corporate functions are generally considered to be high value added activities (Forfás 2003). Manufacturing is often seen as a relatively lower value added activity in pharmaceuticals, although the level of value added in active ingredients is higher than in drug formulations. Process R\&D and sales and marketing are in turn generally characterised as medium-level. A complementary way to account for the level of value creation is to consider the skill/education levels and the number of highly skilled staff involved in pharmaceutical activities and production in a particular locality.

In reality, as will become clear, most of the segments of the value chain involve a number of activities with different characteristics in terms of value creation. The remainder of this paper analyses Ireland's changing role in global production networks, focusing on manufacturing of active ingredients and drug formulations, and $\mathrm{R} \& \mathrm{D}$ in the areas of discovery, clinical trials and process development.

\section{Manufacturing}

Pharmaceutical manufacturing includes the manufacture of active ingredients (the drug substance), drug formulations (the actual tablet, capsule or injection material) and inputs into these items. Active ingredients, which are responsible for the pharmacological effect, are the most important ingredients of the drug formulation. Drug formulation and active ingredients involve different manufacturing processes. Active ingredients can be manufactured by chemical synthesis, extraction, cell culture/fermentation or by recovery from natural sources. Chemical synthesis has long been the most important route, but biotechnology has been growing in importance as a sub-sector since the 1990s. In drug formulation, the active ingredient is combined with other inactive ingredients (excipients) in a physical transformation process involving activities such as granulation, drying, blending and compressing.

The manufacture of active ingredients through chemical synthesis is a multi-stage process. Chemical ingredients are combined into new molecules in a number of chemical synthesis steps. The required inputs can be categorised into regulatory starting materials, basic raw materials and reagents. The regulatory starting materials are substantial fragments of the active ingredient molecule that are specified in the process filed with the regulatory authorities. They are specific to the product and custom made. These are combined with the basic chemicals and reagents in several chemical transformations. The distinction between active ingredient and input production is flexible, depending on the number of steps the pharmaceutical company decides to conduct in house or to outsource. The basic 
chemicals such as solvents are more general and are used by a variety of industries. The reagents are speciality chemicals that may be produced for use in particular types of chemical reaction by a large number of pharmaceutical companies.

The other important route to manufacture active ingredients involves biotechnological processes. Advances in biotechnology have made it possible to genetically manipulate specific bacterial or mammalian cells that produce the required proteins. The manufacturing process of the active ingredient involves two steps: the growing of cells in bioreactors (the upstream process) and the subsequent separation/purification of the protein (the downstream process). The process involves a more limited amount of inputs, notably media, buffers and resins. Bio-fermentation is a frontier technology that typically involves relatively highly skilled personnel.

Figure 3 charts employment growth in different sub-sectors of the pharmaceutical industry in Ireland. It shows that most employment growth was accounted for by the drug formulations sub-sector (drug products in the diagram) and the relatively higher value added active ingredients sub-sector (drug substance in the diagram). Very few companies manufactured other intermediates (van Egeraat 2006).

\section{Active ingredients}

The multinational pharmaceutical firms that invested in Ireland in the 1960s and 1970s were models of Fordist industrial organisation that was associated with a distinct geography of production and R\&D (Malecki 1997, Hayter 1998, Dicken 2007). The geography of production was characterised by a decentralisation of manufacturing functions. Companies established branch plants in numerous markets to overcome trade barriers and to avail of local tax incentives. Until the 1990s, the typical active ingredients plant established by foreign pharmaceutical companies in Ireland was a high volume production plant, producing one or a limited number of active ingredients for a limited number of formulation plants. Typically a company would have started producing the product in one of the new-product-introduction plants, or launch plants, in its home country. The manufacturing process was typically fully developed and all process issues ironed out before the product was transferred to a high volume plant in Ireland. The main drivers for investment in Ireland included low corporation tax and relatively low wages, given that the labour force was sufficiently skilled. The low rate of corporation tax was particularly important for the manufacture of high-value active ingredients. Most major pharma companies invested in at least one overseas high volume active ingredients production plant in one of only three countries or territories that offered a similar package of tax and other incentives: Ireland, Puerto Rico or Singapore.

After the 1990s the flow of investment in active pharmaceutical ingredient (API) manufacturing capacity to Ireland continued unabated. The aggregate growth figures mask important qualitative changes in Ireland's role, raising the level of value creation: notably an increase in launch activities, a focus on the later stages of the chemical synthesis cycle, and the attainment of global manufacturing mandates. The growth of biotechnology gave rise to further qualitative changes.

In relation to Ireland's increasing role in launch activities, it had always made sense from a taxation perspective to establish launch plants and begin production of new chemical entities in Ireland. However, launch plants and the related process development activities require relatively high skills that were not available initially in 
sufficient quantities. This situation changed over the course of the last two decades. Partly in response to the recognised requirements of the pharmaceutical industry, the Irish Government invested significant resources to increase the output of graduates with relevant skills. This allowed for a gradual shift of launch manufacturing (and related process development activities - see next section) to plants in Ireland. Many production sites in Ireland became responsible for both new product introductions and high volume production.

This development coincided with changes in the industry's technological and competitive environment. The number of diseases that can be targeted with chemically derived pharmaceuticals is limited and during the 1990s the number of potential blockbuster drugs in the pipeline of the traditional pharmaceutical companies fell sharply. Companies are increasingly relying on smaller volume high-value drugs for niche markets, and new versions of existing drugs, e.g. for new indications or variations of conditions. This increased the amount of new product introductions and the need for 'flexible' multi-product launch plants, as opposed to mono-product plants designed for the synthesis of a specific active ingredient

In addition, in a global context characterised by reduced rates of revenue growth and increasing costs (see van Egeraat and Breathnach 2008), an increasing number of companies began to outsource non-core activities. Although the strategies differ, some companies have started to outsource the early steps of the active ingredient synthesis cycle. Moving back into the synthesis chain, the regulatory requirements tend to be lower and, as a result, skill requirements and the required level of control over the production process diminish. Some companies have outsourced these early stages to fine chemical suppliers that have been assuming an increased role in the production of regulatory starting materials. There is some evidence of a spatiotemporal pattern in outsourcing. At the early stage of the product life cycle, companies add significant value to the product by using their access to technology to optimise the production process. Later, when the marginal benefits of further continuous improvement activities decline and the product moves closer to the end of its patent-protected period, companies start to outsource the mature product, thereby also freeing up capacity for new product introductions. Ireland's rapidly rising wage levels during the Celtic Tiger era provided an extra incentive to use the Irish facilities for the higher value added elements in the manufacturing chain; notably for new product introductions and late stage synthesis.

Very few processes are outsourced to companies in Ireland. Traditionally the basic chemicals and fine chemical supplies were imported from suppliers in the UK and Europe. Over the last decade, however, the pharma companies have increasingly used low-cost suppliers in India and China, though mainly for lower value added supplies. The interviews suggest that some pharma companies remain hesitant to outsource the later stage synthesis to companies in India and China, doubting whether these companies have the requisite technical knowledge and can meet the stringent health and safety standards required to supply the highly regulated EU, Japanese and North American markets. In addition, pharma companies are concerned that disclosed intellectual property may not be protected. This perception is changing however and pharma companies have even begun to contemplate setting up their own API plants in China and India. 
We are now going through an internal discussion. Do we maintain that [production of a particular product in house] going forward or do we go to India and China and outsource those products? And we are now starting to do more of that than we have done in the past. Mainly active ingredients right now [ ... ] a product that would go off patent. So we are using some of these compounds as the vehicles to test that methodology (interview with general manager API plant).

Another qualitative change in Ireland's role concerns a widening of the manufacturing mandates to cover global markets. Since this development is even more significant in the context of drug formulation activities, a full discussion will be included in the next section. The main difference between active ingredients and drug formulation is that active ingredient plants, given their capital intensive nature, have always had relatively wide mandates. Geographical strategies are varied and somewhat idiosyncratic, but it is generally true to say that, until the 1990s, some of the larger firms tended to organise their active plants on a macro-regional basis, with the Irish active ingredient plants supplying European formulation plants. Many of these companies have since adopted a global supply strategy and Irish API plants have become the single global source for a range of companies' active ingredients.

Finally, since 2000, Ireland is emerging as an increasingly important location for biopharmaceutical active ingredient plants (van Egeraat 2006). The rise of biotechnology, besides introducing a new high-tech production activity to the Irish pharmaceutical space, has also changed Ireland's relative role in global manufacturing networks.

Biotechnology is still a frontier science and the production of active ingredients requires highly skilled staff - even more skilled than in the case of chemical synthesis. In addition, biofermentation requires a greater process $\mathrm{R} \& \mathrm{D}$ effort, a substantial amount of which needs to take place at the site of the commercial manufacturing plant, which further increases skill requirements. By way of illustration, nearly $60 \%$ of all staff at one of the interviewed biopharmaceutical active ingredient plants had third level degrees. The number of locations that can satisfy these skill requirements is more limited than in the case of chemical synthesis. In most cases, the Irish facility is one of only one or two facilities outside a company's home country, making it a strategic facility supplying global markets from the start. Although most of the Irish facilities are established to provide additional capacity for existing products, the intention is that the plants will begin to act as new product introduction plants as soon as new molecules emerge from the development pipeline. The technology and skills requirements mean that at this point in time Ireland competes for inward investment projects with other technologically advanced locations, including Switzerland, rather than with low cost economies. 'At this point in time you would not be looking at China and India for this type of investment' (interview with general manager of biopharmaceutical active ingredient plant). The required inputs - mainly media, buffers and resins - tend to be exclusively sourced from technologically advanced locations in the USA, Europe and Japan.

\section{Drug formulations}

The drug formulations sub-sector has experienced strong growth, particularly since the 1990s. Here too the absolute growth in formulation activity was accompanied by important qualitative changes in Ireland's involvement in global manufacturing 
networks, notably a widening of product mandates to cover European and global markets. Traditionally, tariff and regulatory non-tariff barriers meant that pharmaceutical companies operated separate formulation plants in many different countries (Jungmittag and Reger 2000). The development of the EU single market and new WTO agreements led to increasing harmonisation of regulatory regimes and a reduction of other non-tariff barriers impinging on international trade in pharmaceutical products. The expectation was that the development would lead to a global rationalisation of formulation plants (Howells 1992).

Although we have no global data indicating the extent of this rationalisation, it is known that several companies comprehensively reorganised their manufacturing organisation (Forfás 1995, EFPIA 2003). These companies concentrated production in fewer super-manufacturing plants, although even after the rationalisation most companies still retained a significant amount of formulation plants in different markets, partly due to the fact that significant non-tariff barriers persisted (White 2000a).

Ireland was strongly positioned to benefit from this trend. First, due to the small size of its market, Ireland never had had much leverage over pharma companies to establish small local market-oriented plants. As a result, there were relatively few small-scale inefficient plants to rationalise and many plants already served export markets. Secondly, the attractive taxation regime, low labour costs and the presence of sufficiently skilled labour made Ireland an attractive location for consolidated manufacturing operations. The classic example in Ireland is the Wyeth Medica plant in Newbridge. As part of a global restructuring process, this plant was established to consolidate the formulation activities of 13 manufacturing plants in Europe that had been closed down. The Irish facility is one of the company's two 'strategic' formulation plants (the other one is located in Puerto Rico) producing a large number of products, often for world markets. An indication of the trend towards global supply mandates is that 31 out of about 80 pharma plants that operated in Ireland in 2006 were approved to supply the US market (Interview with manager pharmaceutical division, IDA Ireland 2005; see also McCall 2004).

Besides this widening of the geographical product mandates, some of the qualitative changes discussed under active ingredients are applicable to formulation manufacturing, though not always to the same extent. Many formulation plants have obtained launch plant status and are thus responsible for the relatively skill-intensive new-product introductions (and related process development activities - see below). The strategic nature and know-how, in combination with now higher labour costs, mean that the plants tend to be used for the most value-added markets and stages in the product life-cycle. Many plants focus on the introduction of new products. Nearer to patent expiry the same products are outsourced or left to the specialised generics companies. In addition, the plants in Ireland tend to focus on the more regulated, more technology intensive, and therefore higher value-added markets, notably the USA and EU. 'They [some of the formulation plants in low cost locations] are low cost operations, serving the local market. They would not have the capacity or sophistication to supply into Europe or US. For us to supply those small markets from this plant would be a distraction. Our primary focus is Europe and US' (interview with general manager, formulation plant).

As to the competition from other locations, while most companies have production plants in Eastern Europe, India and China to supply the local markets, 
the interviewees still consider these countries substantially less attractive than Ireland as a location for the formulation of patented drugs for the strongly regulated markets such as the EU and USA. However, as in the case of active ingredients, interviewees typically contend that the growing capability in these regions, in combination with rising costs in Ireland, have the potential to jeopardise Ireland's position in the medium term.

\section{Research and development}

The Fordist geography of $R \& D$ differed from that of production. On an international level, the R\&D functions of multinational companies, particularly the more strategic activities, remained firmly located in the companies' home countries. Some decentralisation of R\&D occurred, but such units were typically small and limited to short-run adaptations of mature products (Hayter 1998). Until the 1980s, the pharmaceuticals sector followed this locational model closely, with basic research functions conducted in the central research units located near the head offices and main production sites of the companies. Branch plants frequently housed small technical and development units, but the scope of such activities was limited (Howells 1984). Even in the case of process R\&D, the manufacturing process was typically for the most part developed by the central R\&D group located near the head office and then transferred to the manufacturing function and manufacturing sites.

This model of R\&D involved inherent structural and operational inefficiencies. Growing competitive and commercial pressures in the post-Fordist period have forced firms to address these inefficiencies resulting in a significant reconfiguration of the spatial organisation of $\mathrm{R} \& \mathrm{D}$. The following sections analyse Ireland's changing role in three of the main components of pharmaceutical-industry R\&D, namely discovery, clinical development and process development.

\section{Discovery}

The discovery stage is concerned with research into the causes of diseases and the identification of compounds relevant to particular diseases. A large number of these leads are assessed for their biological activity. The discovery stage ends with the selection of one or a small number of drug candidates that are believed to have the potential for further development.

In the face of renewed competitive pressures and technological change, pharmaceutical companies have profoundly reorganised their discovery functions. Although most of the discovery research is still done in the laboratories of the companies' home countries (Agrawall 1999), discovery activities have become truly international. In addition, firms increasingly rely on external sources of knowledge, notably dedicated biotechnology firms. Apart from the establishment of overseas R\&D laboratories, the internationalisation process takes many other routes such as the establishment of alliances and joint ventures between large pharmaceutical companies, R\&D co-operation and licensing agreements with dedicated biotechnology firms, pre-competitive research collaboration with universities, and the financing of university research (Reger 2000). As regards their internal R\&D activities, most 
large pharmaceutical companies have now created globally integrated networks of research units, often specialised in a particular disease or technology (centres of excellence). Although strongly internationalised, the discovery research units are highly concentrated in a relatively small number of countries (Taggart 1993, Schweitzer 1997, Lane and Probert 2005) and, within these, in a small number of global 'megacentres' that offer important pools of specialised skills and facilitate knowledge exchange (Cooke 2005, Zeller 2004).

The internationalisation of discovery has largely bypassed Ireland. In 1999, there was little or no drug discovery conducted in Ireland (ICSTI 1999) and this situation has changed little. None of the 11 multinational companies interviewed for this research had a formally constituted discovery laboratory in Ireland. All companies had multiple discovery laboratories in several countries. All had one or more discovery laboratories in the USA, while eight had at least one laboratory in the UK. The main second tier locations included Switzerland ( 3 companies), France (3) and Spain (3).

The IDA never targeted the large-scale discovery laboratories. It was not considered a realistic option because, until recently, the relevant science and technological infrastructure in Ireland was poor by international standards. In 1999 there were no world class universities or centres of excellence and universityindustry co-operation was superficial, short-term and under-funded (ICSTI 1999). This situation has changed profoundly since 2000 when the Irish Government started to invest heavily in the national science and technology infrastructure. Science Foundation Ireland has funded a large body of academic researchers and research teams involved in basic research, notably in the field of biotechnology. These developments are unlikely to be sufficient to attract large scale discovery units of multinational companie, however, as the pharmaceutical companies interviewed continued to rate the chance of their companies establishing discovery functions in Ireland as low or very low.

Although not sufficient to attract large scale discovery units of multinational companies, the upgraded science base has increased Ireland's role in the internationalised discovery networks of the pharmaceutical industry in an indirect way. Through the SFI-funded university-industry collaborations known as Centres of Science Engineering and Technology (CSETs), several Irish universities are now directly co-operating with international pharmaceutical companies in basic research projects. In addition, more recently, the IDA has recognised that the upgraded technology base provides a new opportunity for attracting foreign investment in applied research, and a small number of multinational pharmaceutical companies are now directly employing staff, integrated in applied research groups at Irish universities. Finally, the growing body of Irish scientists, in combination with startup funding provided by Enterprise Ireland, has resulted in the growth of indigenous campus and start-up companies in the area of pharmaceuticals and biotechnology. A small number of these research-focused companies have established collaboration agreements with major pharmaceutical companies. Although these developments are encouraging, the number of start-up companies that have brought products to clinical trials stage is small, and Ireland's involvement in drug discovery in general remains limited by international standards. 


\section{Clinical trials}

Clinical studies involve the testing and evaluation of new drug candidates on human subjects in randomised controlled trials. The core activities include the collection, management and analysis of highly codified clinical data as well as project management and support. Due to increasingly stringent regulatory requirements, clinical studies can now take between 6 and 10 years, depending on the therapeutic area, and have become the greatest cost factor in bringing a new drug to market (Chiesa 1996, Reger 2000, Schofield 2001).

The clinical trials process is typically organised through a three-tiered structure. The product team within the pharmaceutical firm integrates the trial results into the drug development plan. Secondly, the clinical monitors project/manage the trials and oversee the quality of the data. Clinical monitoring mainly concerns the routine manipulation, storage, and transfer of codified data, though the monitors also have a role in problem identification and mediating disputes. Finally, the group of clinical investigators enrol patients into the study and oversee test patients at the clinic (Azoulay 2003).

A large part of the actual data collection activity takes place in a variety of clinics whose work is financed by the pharmaceutical companies. Many hospitals have developed dedicated centres to facilitate clinical trials work. The clinical monitoring activities were traditionally conducted by the pharmaceutical companies ${ }^{6}$ clinical operations groups, and large companies continue to operate a number of clinical research units located in different parts of the world. However, since the 1980s, the monitoring and data management activities have been increasingly outsourced to specialised Clinical Research Organisations (CROs). These CROs are typically involved in the operational aspects of the study with little or no input into the more knowledge-intensive elements of the monitoring activities. As such, the CROs have been characterised as 'data sweatshops', and their employees as 'data mules'. (Azoulay 2003).

Clinical trials have been identified as an important opportunity to increase Ireland's involvement in high value added activities in the pharmaceutical industry, (Forfás 2003, ICSTI 2003, Enterprise Strategy Group 2004) and IDA Ireland is specifically targeting this segment. Recently, a number of universities established the Irish Clinical Research Network in an attempt to fill the gaps in Ireland's clinical research infrastructure. Until now the efforts have had limited success and clinical trials remain under-represented in Ireland (Forfás 2003, Brennan 2008). Apart from the dedicated clinical research centres connected to major hospitals (Beaumont, St. James, Vincent's), direct investment by the private sector has been extremely limited. Exceptions include the clinical research unit of Merck in Dublin and a small number of subsidiaries of international CROs, notably Quintiles.

A number of factors are important in a company's location decision for clinical trials, inter alia: the importance of the market for the drug; a high willingness and ability to cooperate on the part of professional clinics and doctors; strong cooperation with the national approval authorities; efficiency of the ethics commissions involved; and costs, quality and time performance (Reger 2000). The creation of a pan-European clinical research market and unified legal environment (Samsonov 2005) have to some extent reduced Ireland's disadvantage in terms of market size; although the increasingly important pan-European regulatory authorities are located 
outside Ireland (Reger 2000). However, according to one interviewee at a clinical trials unit, a new obstacle for Ireland is that it has become increasingly difficult and expensive to recruit test volunteers.

\section{Process R\&D}

After the identification of a new target molecule in product development, process $\mathrm{R} \& \mathrm{D}$ is responsible for the development of safe and efficient manufacturing processes of commercial scale. The process R\&D cycle of the pharmaceutical industry is complex and involves a number of integrated activities. The various stages of the cycle are listed in Table 6, starting with pre-formulation studies and ending with continuous improvement and the development of generation processes. A detailed discussion of the various activities is beyond the scope of the present paper. For the present discussion it is important to point out that, although all stages can involve skilled and highly educated staff, the early stages in the cycle involve the greatest number of and the most highly skilled researchers. In addition, companies generally aim to have made most major decisions regarding the process prior to phase III clinical trials (activity 7 and 8 in Table 6). From here on, process development focuses on the final details of the process.

Until the mid-1980s, under the Fordist regime, branch plants frequently housed small technical and development units that had some role in process development, but the scope of such activities was limited (Howells 1984). Typically, the

Table 6. Involvement of Irish establishments in process R\&D activities.

\begin{tabular}{|c|c|c|c|c|c|c|c|c|c|}
\hline & \multirow[b]{2}{*}{ Process R\&D activities } & \multicolumn{7}{|c|}{$\begin{array}{l}\text { Likert scale score } \\
\text { (\% of establishments)* }\end{array}$} & \multirow[b]{2}{*}{ mean } \\
\hline & & 1 & 2 & 3 & 4 & 5 & 6 & 7 & \\
\hline 1 & Pre-formulation studies. & 74.6 & 6.8 & 0.0 & 1.7 & 5.1 & 3.4 & 8.5 & 2.0 \\
\hline 2 & $\begin{array}{l}\text { Derivation of initial route/process options } \\
\text { and preliminary evaluation }\end{array}$ & 71.0 & 11.3 & 1.6 & 3.2 & 6.5 & 1.6 & 4.8 & 1.9 \\
\hline 3 & Evaluation in small scale experiments & 63.9 & 13.1 & 3.3 & 3.3 & 4.9 & 1.6 & 9.8 & 2.2 \\
\hline 4 & Evaluation in kilo lab & 62.1 & 10.3 & 5.2 & 1.7 & 5.2 & 6.9 & 8.6 & 2.3 \\
\hline 5 & Production for Phase II clinical trials & 52.8 & 13.2 & 5.7 & 5.7 & 7.5 & 1.9 & 13.2 & 2.6 \\
\hline 6 & $\begin{array}{l}\text { Evaluation and optimisation in pilot plant } \\
\text { prior to Phase III clinical trials }\end{array}$ & 39.6 & 17.0 & 17.0 & 7.5 & 5.7 & 5.7 & 7.5 & 2.7 \\
\hline 7 & Production for Phase III clinical trials & 25.9 & 5.6 & 9.3 & 9.3 & 14.8 & 16.7 & 18.5 & 4.1 \\
\hline 8 & $\begin{array}{l}\text { Evaluation and optimisation in pilot plant } \\
\text { during Phase III clinical trials }\end{array}$ & 27.8 & 9.3 & 14.8 & 7.4 & 16.7 & 13.0 & 11.1 & 3.6 \\
\hline 9 & Equipment design & 9.7 & 9.7 & 11.3 & 14.5 & 19.4 & 19.4 & 16.1 & 4.5 \\
\hline 10 & $\begin{array}{l}\text { Optimisation in commercial plant (pre } \\
\text { filing) }\end{array}$ & 4.8 & 3.2 & 3.2 & 6.5 & 16.1 & 21.0 & 45.2 & 5.7 \\
\hline 11 & Validation & 0.0 & 0.0 & 3.2 & 4.8 & 6.5 & 22.6 & 62.9 & 6.4 \\
\hline 12 & Continuous improvement & 0.0 & 1.6 & 0.0 & 1.6 & 9.7 & 21.0 & 66.1 & 6.5 \\
\hline 13 & $\begin{array}{l}\text { Development of second generation process } \\
\text { (outside filing parameters) }\end{array}$ & 9.8 & 8.2 & 14.8 & 4.9 & 14.8 & 11.5 & 36.1 & 4.9 \\
\hline
\end{tabular}

*Note: $1=$ no input in activity by Irish plant; $7=$ Irish plant has sole ownership of activity. 
manufacturing process was for the most part developed by the central R\&D group located near the head office and then transferred to the manufacturing sites.

The results of the email survey of all pharmaceutical companies in Ireland show that the role of Ireland in the global process R\&D networks of multinational pharmaceutical companies has changed since the mid-1980s (see also van Egeraat (2007). In the period 2000-2006, the number of people involved in process R\&D almost doubled, from 408 to 800 , compared with a $36 \%$ growth rate in total employment over the period.

To get an insight into the relative role of the Irish plants in the global networks of their parent firms, survey respondents were asked to rate the input of the local staff in various process $R \& D$ activities of the parent firm on a seven-point Likert scale (where a score of 1 indicated that the Irish plant had no input in the activity and a score of 7 indicated that the Irish plant had sole ownership of the activity in question). The findings of this question are presented in Table 6. The columns represent the proportion of relevant establishments falling into each Likert scale score category while the 'mean' column indicates the mean score obtained for all respondent establishments for the relevant R\&D activity

Although there are important differences between individual companies, the data clearly show that the involvement of the Irish staff in process R\&D only becomes substantial after the proof-of-concept point, at the beginning of phase III clinical trials. ${ }^{5}$ As mentioned earlier, this is the point at which companies generally want to have locked down the process parameters. From here on, process R\&D activities focus on the final details of the process and technology transfer. The fact that the Irish establishments tend to concentrate their involvement in process R\&D activities in the later stages of the cycle does not mean that they are involved in low-skilled or mundane activities. The education profile of staff involved in process R\&D can be used as an indicator of the quality or sophistication of the activities carried out in the Irish subsidiaries. The survey shows that process $R \& D$ activities in the Irish pharmaceutical sector employ a substantial number of highly skilled people, with $30 \%$ of the 800 people involved holding a $\mathrm{PhD}$ degree as their highest level of academic attainment, with 19\% having a Master's degree, and a further $46 \%$ holding a primary degree.

The change in Ireland's role in process R\&D activities is the result of several partly integrated drivers (van Egeraat and Breathnach 2008). First, reacting to increasing costs of developing new products alongside pressure on drug prices and revenues, pharmaceutical companies have begun to organise their process development function more effectively. The required co-ordination between the various stages of the process development cycle and between process development and manufacturing functions has been achieved by co-locating selected process R\&D functions at manufacturing plants, including in Ireland. Another important driver lies in the international taxation regime, notably the introduction in the mid-1990s of US legislation for cost-sharing arrangements for developing intellectual property. This provided an instrument for US multinationals to share the costs of developing intellectual profits between various subsidiaries, and thereby shifting some of the profits to subsidiaries in lower-tax jurisdictions, including Ireland. The location in Ireland of functions additional to manufacturing, notably R\&D pilot plants, could be used to justify higher levels of value added and profits attributed to the Irish subsidiaries. Finally, a number of measures implemented by the Irish Government in 
recent years have also exerted a positive influence on the disposition of pharmaceutical MNEs towards locating process R\&D activities in Ireland without necessarily being a key driver, namely: the investment in education and the resulting rapid growth in the supply of science and technology graduates discussed earlier; the major expansion of state funding of scientific research; tax credits for R\&D expenditure and grant schemes to support R\&D initiatives.

\section{Conclusion}

Mainly driven by foreign direct investment, employment and export levels of the Irish pharmaceutical industry have grown substantially over recent decades, and Ireland has become one of the main pharmaceutical exporters. The growth continued after 2002, at a time when most other manufacturing sectors in Ireland experienced decline. This growth is positive in itself, particularly in light of the fact that the pharmaceutical sector is one of the most skill-intensive manufacturing sectors in Ireland. From a dynamic regional development perspective it is also interesting to explore the qualitative changes in the types of activities that are conducted in Ireland. Adopting a global production network approach for examining regional development in the context of globalisation, the paper examined Ireland's changing role in global production networks within the pharmaceutical industry, focusing on the different components of manufacturing (i.e. active ingredients and drug formulations) and R\&D (i.e. discovery, clinical trials and process development).

Within manufacturing, there has been very little growth in the (relatively) low value generating activity of basic chemicals. Employment growth instead occurred mainly in drug formulation and the higher-value-generating active ingredients subsector. Alongside this, Irish plants have assumed a greater role in launch activities, an increased focus on the later stages of the chemical synthesis cycle, and a geographical widening of product mandates. All these developments have substantially increased the level of value creation. A similar evolution is apparent in certain segments of the computer hardware sector and in computer services (van Egeraat and Jacobson 2004, Barry and van Egeraat 2008).

Ireland's role in pharmaceutical R\&D differs considerably from activity to activity. Notwithstanding recent developments in Irish third-level institutions and the growing number of indigenous research-based companies, Ireland's relative role in the high value generating drug discovery field remains very limited. Similarly, in spite of efforts to upgrade the necessary infrastructure, high value generating clinical trials activities remain under-represented in Ireland. Finally, Ireland's role in the medium value generating process $R \& D$ activities has increased substantially, with a doubling of the number of people involved over the period 2000-2006. Even in this area however, Ireland's involvement is concentrated in the (relatively) lower value generating down-stream phases of the cycle.

Although the picture is complex and differentiated, the level of value creation in the Irish pharmaceutical industry has increased substantially over the Celtic Tiger era. In spite of an increasing number of indigenous research-focused start-up companies however, the sector remains strongly dominated by foreign investment so that a large share of the value created is not captured within Ireland. 


\section{Acknowledgements}

The research for this paper was partly supported by a grant from the Irish Research Council for the Humanities and Social Sciences. The authors would like to thank Peter Dicken, Neil Coe and Martin Hess for sharing their experience in researching Global Production Networks. In addition we would like to thank two anonymous referees for their constructive comments

\section{Notes}

1. Data from intracen.org (the International Trade Centre, a joint facility of UNCTAD and the WTO).

2. As Desai et al. (2006) point out, 'OECD governments require firms to use transfer prices that would be paid by unrelated parties, but enforcement is difficult, particularly when pricing issues concern differentiated or proprietary items such as patent rights. Given the looseness of the resulting legal restrictions, it is entirely possible for firms to adjust transfer prices in a tax-sensitive fashion without violating any laws.'

3. Stewart (1989) provides further evidence indicative of such practices.

4. Henderson et al. 2002, for example define value as 'a combination of the Marxian notion of surplus value with more orthodox notions of economic rent'.

5. A detailed analysis of the differences between companies is beyond the scope of this article but it is interesting to note one example related to national culture. Corporate strategy towards the management of global production networks and the level of internationalisation of R\&D is believed to be strongly related to the nationality of the lead firm (Dicken 2007). The detailed case study of a Japanese pharmaceutical firm suggests that the particular spatial configuration and organisational co-ordination at this firm is indeed related to culture. The technical support group at this Japanese facility has a very limited role in process $\mathrm{R} \& \mathrm{D}$. The technology transfer is carried out by staff flown in from Japan. 'It is not a consultative process, let's put it that way. (...) I worked for a Japanese and American company and they both have very different ways of doing tech transfer. (...) If you look at European or American subsidiaries, they have a lot more autonomy and there is a lot more expected of them and I think in Japanese companies, knowledge is key and the retention of knowledge is paramount to a certain extent. So, I am not sure how much really they are going to give over. I think it is very much a cultural thing.' (Manager, technical support unit, Japanese pharmaceutical plant)

\section{References}

Agrawall, M., 1999. Global competitiveness in the pharmaceutical industry: the effect of national regulatory, economic and market factors. New York: Pharmaceutical Products Press.

Amin, A., Bradley, D., Howells, J., Tomaney, J., and Gentle, C., 1994. Regional incentives and quality of mobile investment in the less favoured regions of the EC. Progress in Planning, 41 (1), 1-112.

Azoulay, P., 2003. Acquiring knowledge within and across firm boundaries: evidence from clinical development. NBER working paper 10083. Cambridge: National Bureau of Economic Research.

Bair, J. and Gereffi, G., 2001. Local clusters in global chains: the causes and consequences of export dynamism in Torreon's blue jeans industry. World Development, 29 (11), 1885-1903.

Barry, F., 2005. FDI, transfer pricing and the measurement of R\&D-Intensity. Research Policy, 34 (5), 673-681.

Barry, F. and van Egeraat, C., 2008. The decline of the computer hardware sector: how Ireland adjusted. ESRI Quarterly Economic Commentary, Spring, 38-57.

Bartlett, C. and Ghoshal, S., 1989. Managing across borders. Boston, MA: Harvard Business School Press.

Beesley, A., 2005. US firm in €1bn return from Irish unit. Irish Times, 12 October, p. 20.

Brennan, C., 2008. Pharma head backs Ireland as base for clinical trials. Irish Times, 25 July, p. 18.

Census of Industrial Production, 2004. Dublin: Central Statistics Office.

Childs, P., 1996. The chemical industry in Cork. Chemistry in Action, 47. 
Chiesa, V., 1996. Separating research from development: evidence from the pharmaceutical industry. European Management Journal, 14 (6), 638-647.

Coe, N., Hess, M., Yeung, H., Dicken, P., and Henderson, J., 2004. Globalizing regional development: a global production networks perspective. Transactions of the Institute of British Geographers, 29, 464-84.

Cooke, P., 2005. Rational drug design: the knowledge value chain and bioscience megacentres. Cambridge Journal of Economics, 29 (3), 325-341.

Desai, M., Foley, C.F., and Hines, J.R.Jr., 2006. The demand for tax haven operations. Journal of Public Economics, 90, 513-531.

Dicken, P., Kelly, P., Olds, K., and Yeung, H., 2001. Chains and networks, territories and scales: towards a relational framework for analysing the global economy. Global Networks, 1 (2), 89-112.

Dicken, P., 2007. Global shift: mapping the changing contours of the world economy. London: Sage Publications.

EFPIA, 2003. The pharmaceutical industry in figures. Brussels: European Federation of Pharmaceutical Industries and Associations.

Enterprise Strategy Group, 2004. Ahead of the curve: Ireland's place in the global economy. pharmaceutical biotechnology sector report. Dublin: Forfás.

Forfás, 1995. Transport needs of Irish manufacturing sectors. Dublin: Forfás.

Forfás, 2003. The Supply and demand for skills in the biotechnology sector. Dublin: Forfás.

Galvin, S., 1998. The chemical industry in Ireland. Chemistry in Action, 54, 9-16.

Gerreffi, G., 2001. Shifting governance structures in global commodity chains, with special reference to the internet. American Behavioural Scientist, 44 (10), 1616-1637.

Gereffi, G. and Korzeniewicz, M., eds., 1994. Commodity chains and global capitalism. Westport, CT: Praeger Publishers.

Hayter, R., 1998. Research and development. In: P. Daniels and W. Lever, eds. The global economy in transition. Harlow, UK: Longman, 64-190.

Hedlund, G. and Rolander, D., 1990. Actions in heterarchies: new approaches to managing the MNE. In: C. Bartlett, Y. Doz and G. Hedlund, eds. Managing the global firm. London: Routledge, 15-46.

Henderson, J., Dicken, P., Hess, M., Coe, N., and Yeung, H., 2002. Global production networks and the analysis of economic development. Review of International Political Economy, 9 (3).

Hudson, R., 1994. New production concepts, new production geographies? Reflections on changes in the automobile industry. Transactions of the Institute of British Geographers, 19 (3), 331-345.

Hudson, R., 1997. Regional futures: industrial restructuring, new high volume production concepts and spatial development strategies in the new Europe. Regional Studies, 31 (5), 467-478.

Howells, J., 1992. Pharmaceuticals and Europe 1992. Environment and Planning A, 24, 33-48.

Howells, J., 1984. The location of research and development: some observations and evidence from Britain. Regional Studies, 18 (1), 13-29.

ICSTI, 1999. Technology foresight Ireland. Dublin: Irish Council for Science Technology and Innovation.

ICSTI, 2003. Embedding the pharmachem industry in Ireland. Dublin: Irish Council for Science Technology and Innovation.

International Trade Centre online database, available at http://www.intracen.org.

Jungmittag, A. and Reger, G., 2000. Dynamics of the markets and market structure. In: A. Jungmittag, G. Reger and T. Reiss, eds. Changing innovation in the pharmaceutical industry: globalisation and new ways of drug development. Berlin: Springer-Verlag, 27-47.

Lane, C. and Probert, J., 2005. Innovation systems, globalisation and performance in the pharmaceutical industry: German and UK firms compared. Paper presented at the conference Organisational Configurations and Locational Choices of Firms: Responses to Globalisation in Different Industry and Institutional Environments. University of Cambridge, 14-15 April.

Malecki, E., 1997. Technology \& economic development: the dynamics of local, regional and national competitiveness. Harlow, UK: Addison Wesley Longman. 
McCall, B., 2004. A dose of good medicine. Irish Times, 2 July, p. B6.

Phelps, N., 1993. Contemporary industrial restructuring and linkage change in an older industrial region: examples from the Northeast of England. Environment and Planning A, 25 (6), 863-882.

Pike, A., 1998. Making performance plants from branch plants? In situ restructuring in the automobile industry in the United Kingdom. Environment and Planning A, 30 (5), 881-900.

Piore, M. and Sabel, C., 1984. The second industrial divide. New York: Basic Books.

Population Census, 2006. Dublin: Central Statistics Office.

Reger, G., 2000. Internationalisation of Research and development in pharmaceuticals. In: A. Jungmittag, G. Reger and T. Reiss, eds. Changing innovation in the pharmaceutical industry: globalisation and new ways of drug development. Berlin: Springer-Verlag, 97-134.

Samsonov, M., 2005. Clinical trials in Central and Eastern Europe. World Pharmaceutical Frontiers, 2004/2005, pp. 74-75.

Schofield, M., 2001. The global pharmaceutical industry. In: P. Kirkbride, ed. Globalisation: the external pressures. New York: John Wiley.

Schweitzer, S., 1997. Pharmaceutical economics and policy. New York: Oxford University Press.

Stewart, J., 1989. Transfer pricing: some empirical evidence from Ireland. Journal of Economic Studies, 16 (3), 40-56.

Sturgeon, T., 2000. How do we define value chains? MIT IPC Globalization Working Paper 00010. Boston: MIT.

Taggart, J., 1993. The world pharmaceutical industry. London: Routledge.

Turok, I., 1993. Inward investment and local linkages: how deeply embedded is 'Silicon Glen'? Regional Studies, 27(5), 401-417.

United Nations Comtrade online database, available at http://comtrade.un.org.

van Egeraat, C., 2006. Spatial concentration in the Irish pharmaceutical industry: the role of government intervention and agglomeration economies. NIRSA Working Paper 28. Maynooth, Ireland: National University of Ireland.

van Egeraat, C., 2007. The scale and scope of process R\&D in the Irish pharmaceutical industry. NIRSA Working Paper 32. Maynooth, Ireland: National University of Ireland.

van Egeraat, C. and Breathnach, P., 2007. The manufacturing sector. In: R. Kitchin and B. Bartley, eds. Understanding contemporary Ireland. Dublin: Pluto Press, 125-146.

van Egeraat, C. and Breathnach, P., 2008. The drivers of transnational subsidiary evolution: the upgrading of process R\&D in the Irish pharmaceutical industry. NIRSA Working Paper 38. Maynooth, Ireland: National University of Ireland.

van Egeraat, C. and Jacobson, D., 2004. The rise and demise of the Irish and Scottish computer hardware industry. European Planning Studies, 12 (6), 810-834.

White, P., 2000a. The muscles of the Celtic Tiger: IDA's winning sectors. In: R. Mac Sharry and P. White, eds. The making of the Celtic Tiger. Cork: Mercier Press, 272-308.

White, P., 2000b. The evolution of the IDA. In: R. Mac Sharry and P. White, eds. The making of the Celtic Tiger. Cork: Mercier Press, 183-197.

White, R. and Poynter, T., 1984. Strategies for foreign owned subsidiaries in Canada. Business Quarterly, 49 (summer), 59-69.

Yeung, H., 2000. Organizing the firm in industrial geography: networks, institutions and regional development. Progress in Human Geography, 24 (2), 301-315.

Yeung, H., Dicken, P., Henderson, J., Hess, M., and Coe, N., 2001. Foreign direct investment, trade, and global production networks in Asia and Europe. Paper presented at the $3^{\text {rd }}$ Annual Global Development Conference on Blending Local and Global Knowledge. Sofitel Rio Palace Hotel, Rio de Janeiro, Brazil, 9-12 December.

Young, S., Hood, N., and Dunlop, S., 1988. Global strategies, multinational subsidiary roles and economic impact in Scotland. Regional Studies, 22(6), 487-497.

Young, S., Hood, N., and Peters, E., 1994. Multinational enterprises and regional economic development. Regional Studies, 28(7), 657.

Zeller, C., 2004. North Atlantic innovative relations of Swiss pharmaceuticals and the proximities with regional biotech arenas. Economic Geography, 80 (1), 83-111. 